Periodica Polytechnica Architecture, 49(1), pp. 77-85, 2018

\title{
How (not) to Design a Landscape
}

\author{
Ján Urban ${ }^{1 *}$, Andrea Lacková1 \\ ${ }^{1}$ Institute of Urban Design and Planning, Faculty of Architecture, Slovak University of Technology in Bratislava, \\ Námestie Slobody 19, 812 45, Bratislava, Slovakia \\ *Corresponding author, e-mail: jan.urban@stuba.sk
}

Received: 14 February 2018, Accepted: 18 April 2018, Published online: 20 April 2018

\begin{abstract}
The article describes some methods of water regulation and the impact that dykes have on the landscape. In the paper, the process of planning the Gabčikovo Waterworks is outlined together with the various solutions for the regulation of the river Danube, and the pros and cons of these variants. The paper aims to report the process of planning from the perspective of the authors, engineers, architects and landscape designers.

For this article, archives were searched for published papers and journals to find the older versions of the regulation proposed for the river Danube. Later, the authors were interviewed about their part in the planning process. The paper seeks to answer the question: To what degree was the impact on the landscape was taken into account?

Where the landscape was dealt with only from the biological and geological point of view, there was no demand for the image or design of the landscape. The result of this process is a drastic change, and it is upon our generation of architects, urban and landscape designers to learn from the past processes of construction and to improve any future changes in a more collaborative and socially oriented way.
\end{abstract}

\section{Keywords}

landscape, architects, Gabčíkovo - Nagymaros Waterworks, process

\section{Introduction}

"The issue of contemporary settlement and the contemporary spread of technology through the landscape should nowadays be one of the main interests of urbanists. However, we cannot only satisfy ourselves, but should also be looking for and finding ways to incorporate a new cultural, technical, or constructional work into the environment as requested by the expert. It is increasingly necessary to ensure that the work in the present country does not cause biological disruption in the life of the country. Consequently, the main question is: Are the primary forms and aesthetic aspects that we are still trying to apply in the country a sufficient criterion?” (Hruška, 1946)

The Gabčíkovo Waterworks is a system of dams and channels on the Danube. It is a large project from the Bratislava Cunovo Dam, the Hrušov reservoir to the Gabčíkovo Dam in the south of western Slovakia (Fig. 1). This paper aims to retrieve information about the construction of the Gabčíkovo Waterworks from the period prior to the works (Fig. 2), during and after the construction. The processes and story of "Gabčíkovo" from outside are well known, but what was happening inside the planning process, specifically, from the viewpoint of planners and architects of the dam? This research examines the role of the architects, urban planners and landscape designers including their discussions, ideas, discourse about the city, landscape and spatial planning. Were the authors considering, during the designing process, how the construction would shape the landscape? What was the context and theoretical discourse of the period concerning river and landscape design?

\section{Methods}

For this article, we collected data from archives, already published papers and journals, and through interviews with the authors of the projects. We demonstrated the various solutions for the waterworks from the journals and papers. The second part of our research was to locate and interview the authors of the projects. We met and talked with architects Martin Kusý, Ilja Skoček and Tadeáš Tholt and the water manager responsible for the Gabčíkovo waterworks Mr. Minárik. 


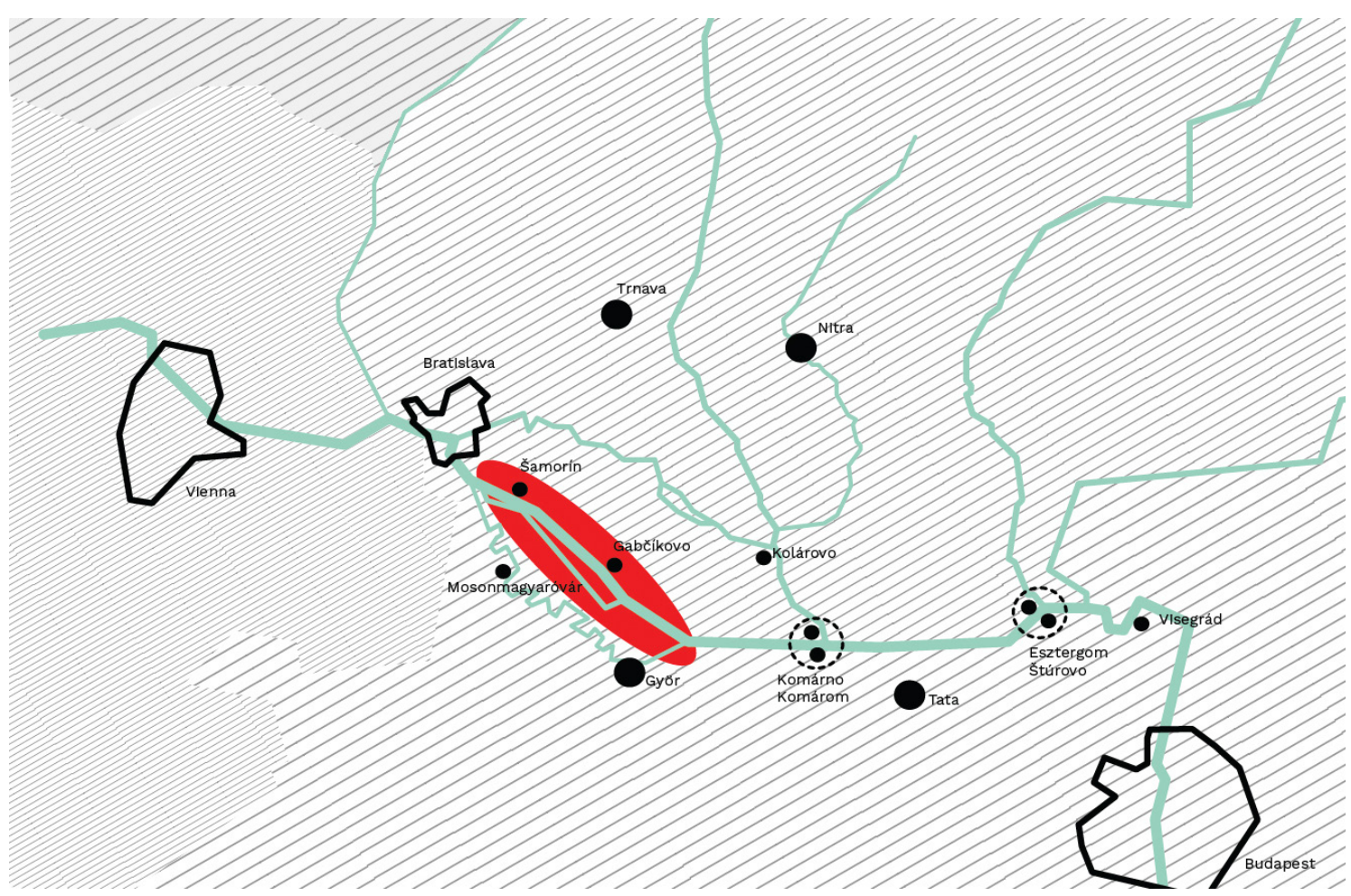

Fig. 1 Location of Gabčíkovo Waterworks, drawing: author

\section{Water Management Theories}

The most influential urban planner of that time in our area was Prof. Emanuel Hruška. He describes in his book, Landscape and its contemporary urbanisation, some of his thoughts about water management. The ideal state, as he describes it, is when mankind is in collaboration with the waters. The perfect and ideal form is in creating dams in the upper parts of the streams to control the spring floods, and for shipping to create an artificial water channel with hydroelectric power stations just next to the natural streams of water (Fig. 3). This was later enacted by Mr. Danišovič on the river Váh and some years later also on the Danube.

The architect, Il'ja Skoček co-author of the Gabčíkovo hydroelectric power station, referred to the strategy that

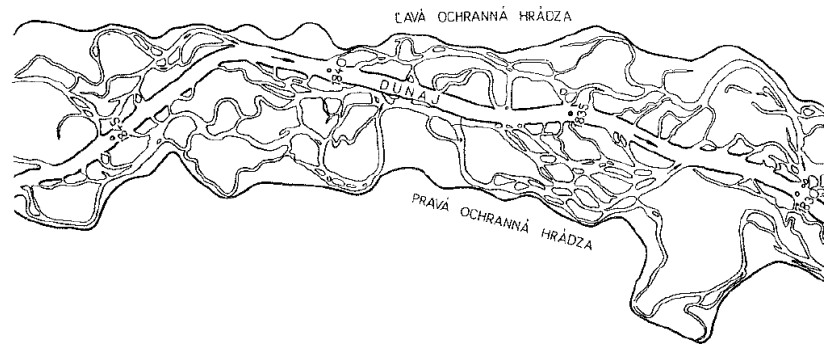

Fig. 2 Danube beneath Bratislava, its arms and dykes before the Waterworks, source: Danišovič, Projekt 150/1971 pp. 398.

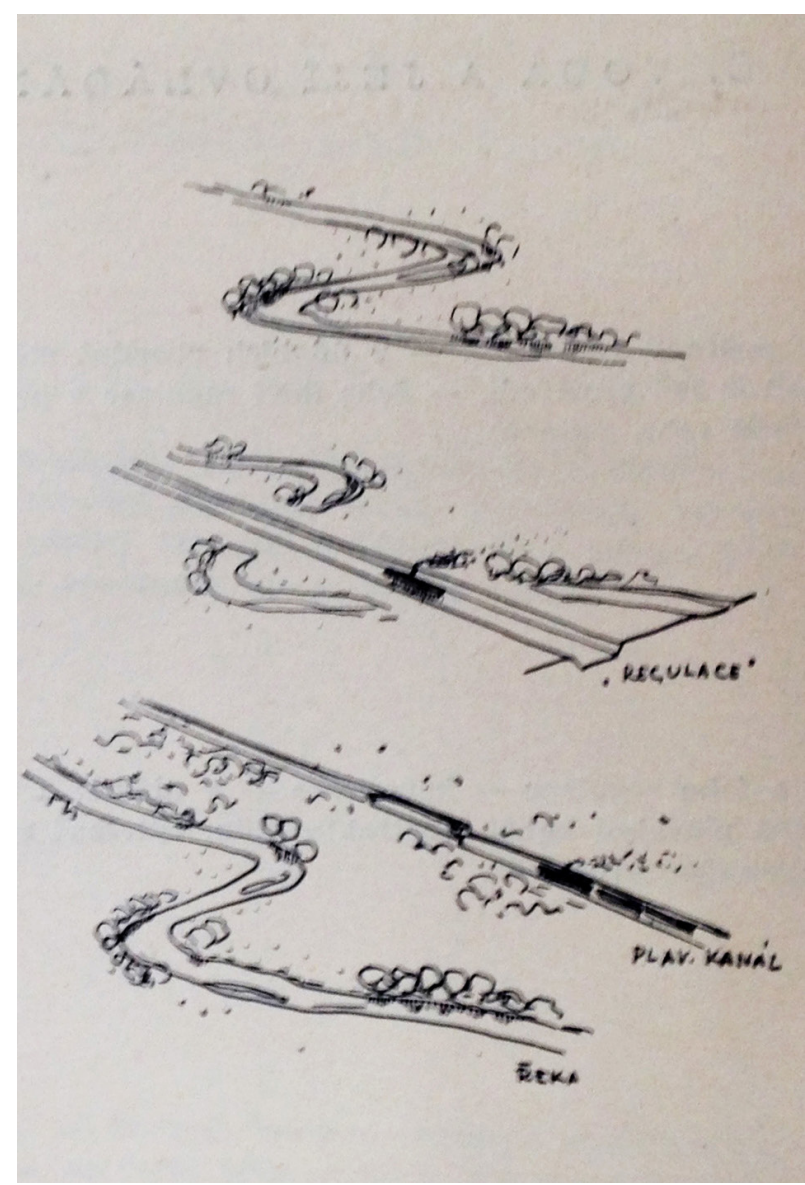

Fig. 3 Source: Hruška (1946, pp. 28.) 
was already working on the river Váh and projected by Mr. Danišovič. He stated:

“... Danišovič had almost ten of the dams on the river Váh completed, including the Orava dam and the so-called Váh cascade as well. The Váh project had the same concept - river, channel, dam, channel and then river again. The Nosice dam was also completed, Madunice, Šal'a, there is always the dam which stops the water, here the channel starts, which leads the water to the hydroelectric power station. It is also easier not to construct it on the river itself."

\section{The Dykes as a Landscape Element}

The topic of the dykes is strongly present in Miček's article:

"Linear constructions (dykes, channels) can add value to the image of the landscape with the help of vegetative design. Many towns and landscapes by the river Váh gained in attractiveness thanks to the built spaces after the construction of the dams. When we realise the economic cost of these aesthetic readjustments, in comparison to the cost of the water management construction, it is clear that no hesitation is needed. We have to handle the water, make it attractive, and put it in the service of man. A common task for the water management engineer and architect is to connect the water with the landscape and the town, make it closer - especially in bigger towns - to citizens." (Míček, 1975)

There is another remark by Danišovič in his article about the impact on the landscape that would be caused by the long and high dykes of the derivation channel (Fig. 4). So, we can assume that there was a discussion on these topics. He compares the presence of the dykes on an already finished project of the dam close to Piešt'any:

"Sometimes there is a doubt among the professional public, will the dykes of the derivation channel be a distorting element in the Danube natural landscape. The strewn dykes will be stretched from Bratislava (rkm 1866) to Hrušov (rkm 1862) as dykes of the river reservoir, and from there to Gabčíkovo (rkm 1820) as dykes of the derivation channel. At Hrušov, the dykes will be $8.5 \mathrm{~m}$ high, at Gabčíkovo $18 \mathrm{~m}$. For comparison, we can provide an example of the river dyke beneath Pieštany. The dykes on the river are $3.65 \mathrm{~km}$ long, 4 to $6 \mathrm{~m}$ high and continue as dykes of the supply channel of the Madunice hydroelectric water station. Here, they are 6 to $12 \mathrm{~m}$ high and $6.54 \mathrm{~km}$ long, but they do not distract from the image of the natural landscape. The Danube derivation channel will be situated on a significantly wider and broader flatland. The proportion of the height to the length and width
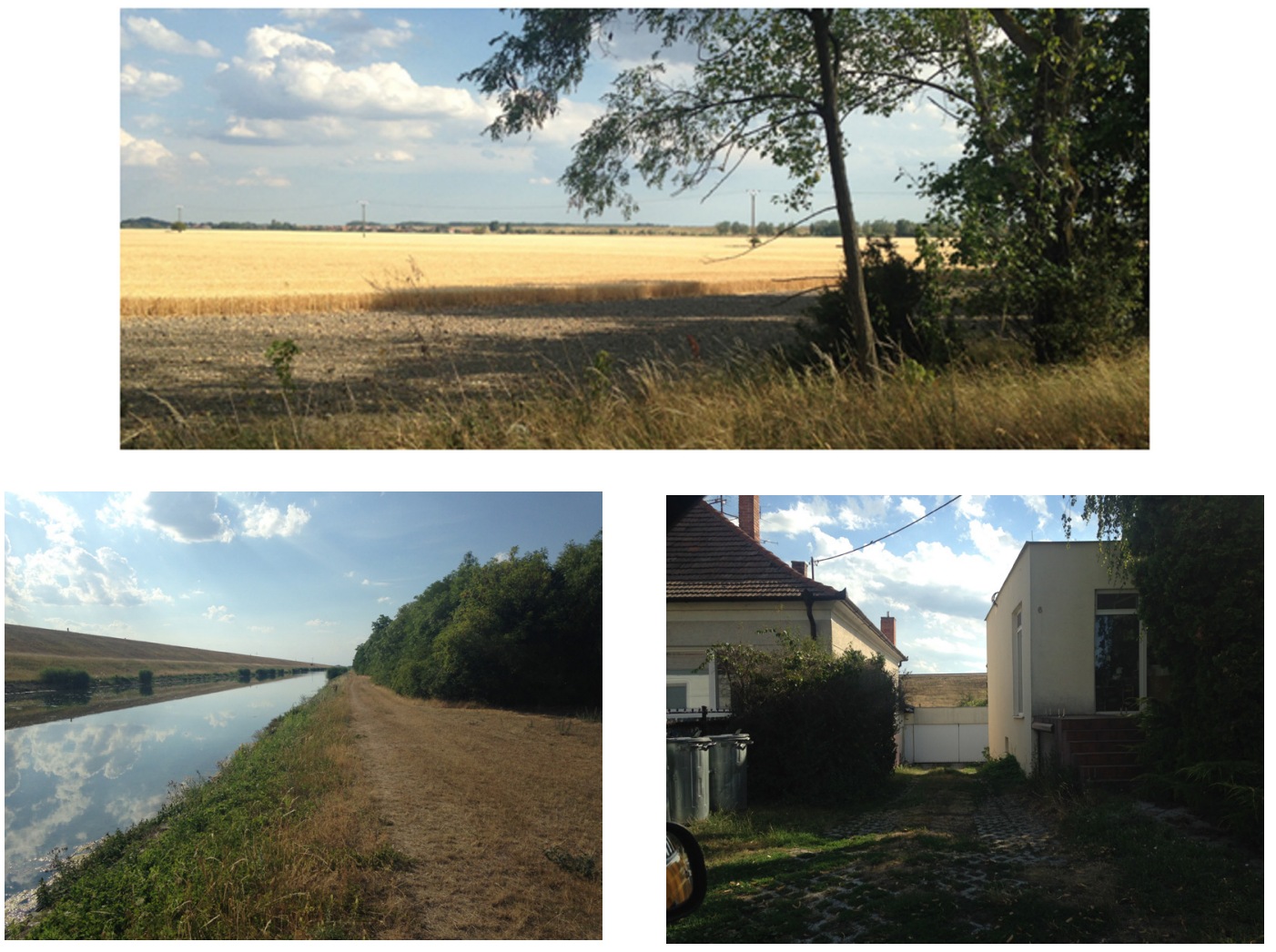

Fig. 4 Photographs of the dykes of the derivation channel and their image in the landscape. Source: author 


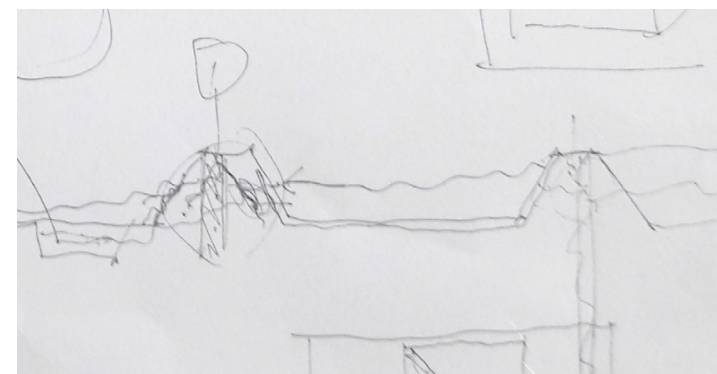

Fig. 5 Sketch of Kusý as part of the interview - dyke with a tree

of the dykes will be much smaller with a much greater viewing distance. The dykes will be green, and the horizontal geometrical contour of the channel will be disrupted by the planting of ensembles of aesthetic trees and bush." (Danišovič, 1971)

As a reaction to this topic, we can cite Mr. Kusý; the collective of Mr. Skoček at ŠPTÚ wanted to design the earth dykes that proceed next to the river.

"The first idea of an architect is to plant a tree on the top of the dyke, but it is not possible. The roots of the trees, together with the water, would destroy the dyke if enough time is given. I wanted to put concrete wells inside the dyke to plant trees in there, but the engineers were too afraid and did not let me try it." (Fig. 5)

\section{Proposals for Regulation on the River Danube}

The prehistory of the waterworks can be found in the works starting in the 19th century by Enea Lanfranconi. In his work, About Waterways in Middle Europe with Special Focus on the Regulation of the River Danube between Thebes and Gönyö (Bratislava, 1879,) he proposed an artificial water channel stretching from Bratislava to Komárno with 11 dams and lock chambers that could also serve as “power plants." (Greguš, 2017) (Fig. 6)

The proposal from a Swiss engineer, Mr. Fischer, dated 1915, was a dam beneath the port of Bratislava with an

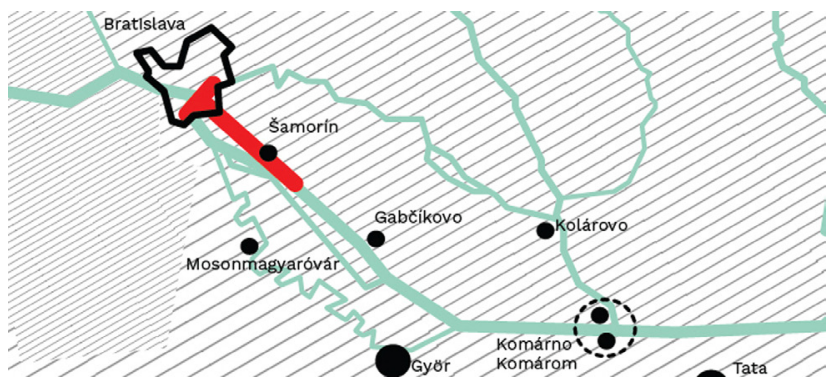

Fig. 7 Fischer's proposal, drawing: author

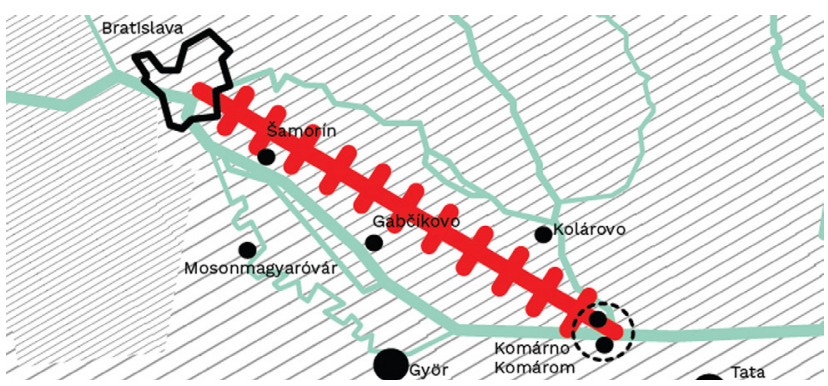

Fig. 6 Lanfranconi's proposal, drawing: author

elevation difference of 3 meters, which would make shipping easier. The water from a reservoir would continue through a channel 20 kilometres long and 100 metres wide. Part of the dam would be a hydroelectric power station. (Fig. 7)

In 1921, Mr. Holeček from the Ministry of Slovakia proposed a third solution that included a water dam next to Bratislava with a hydroelectric power station. The water channel, leading through the town of Šal'a and Kolárovo, with a length of 80 kilometres, width 84 meters and a depth of 9 to 10 meters; it would contain three lock chambers all with hydroelectric power stations. (Čomaj, 2017) (Fig. 8)

After the WWII, Mr. Danišovič took over the work. He was the project manager and engineer of many dams in Slovakia and the author of the regulation of the river Váh. Mr. Lokvenc former manager for the Gabčíkovo Waterworks reported:

"It was in the spring of 1951. I started to work at Hydroconsult (state firm for water management and Waterworks planning) at the office of the former university professor and engineer Peter Danišovič; he told me: "Let's do the Danube!" He is, in reality, the spiritual father of the idea of waterworks on the Danube." (Greguš, 2017)

Mr. Peter Danišovič published his proposal and thoughts about the utilisation of the river Danube in 1971 in the revue Slovak Architects Projekt, with this description of the water channel:

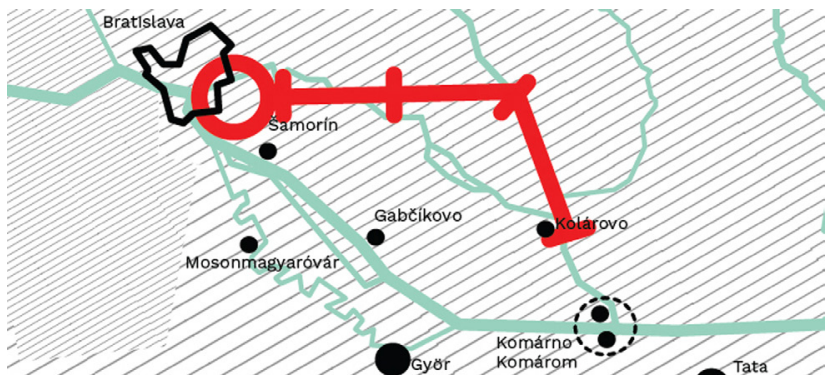

Fig. 8 Scheme of Holeček's proposal, drawing: author 


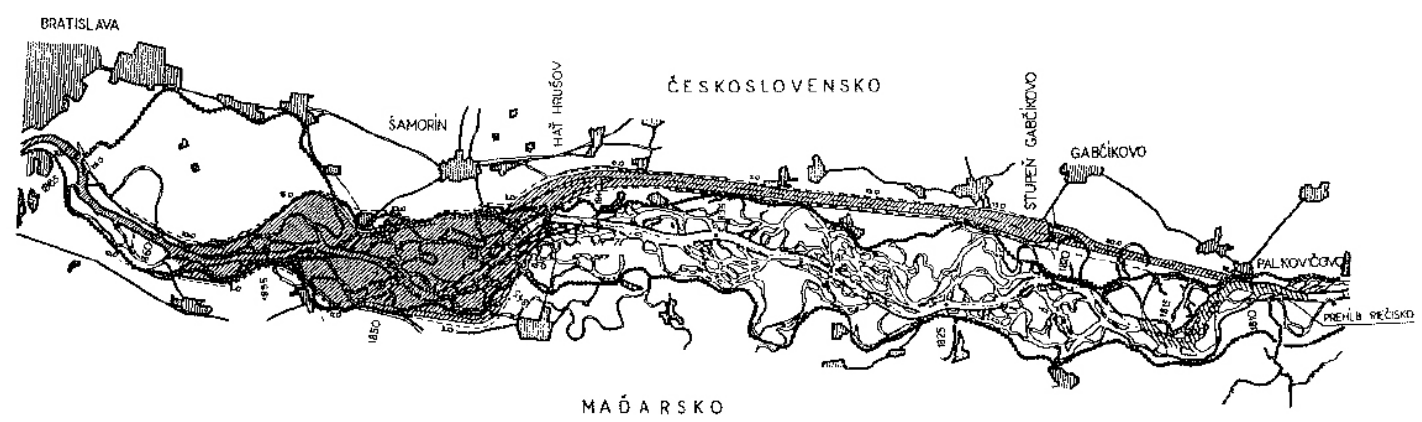

Fig. 9 Scheme of Danišovič's proposal, source: Danišovič, Projekt 150/1971 pp. 402.

"The water channel will shift left from the river Danube approximately at Hrušovo, 1842 river $\mathrm{km}$ (rkm) and will join the river at Polakovičovo, $1810 \mathrm{rkm}$. The broad derivation channel (300 to $650 \mathrm{~m}$ ) will take a lot of fertile agricultural land, will separate from the rest of "Rye Island" (Žitný ostrov) and three settlements (Dobrohošt', Vojka, Bodíky), and will take water from the natural river bed in the stretch between Hrušov and Polakovičovo, so the hydrological and biological conditions will dramatically change in this area."

"The whole Czechoslovak section of the Danube from the confluence with the Morava river to the confluence with the Ipel river will be utilised using three levels. The first, the upper one, to be built $1873.3 \mathrm{rkm}$ above Bratislava as a joint Czechoslovak-Austrian Waterworks - the Wolfstahl/ Bratislava Waterworks. The second one at $1820 \mathrm{rkm}$ at Gabčíkovo as a joint Czechoslovak-Hungarian Waterworks. The third, lower one, at $1696.25 \mathrm{rkm}$ at Nagymaros as a joint Czechoslovak-Hungarian Waterworks on the Danube, each having a floodplain, a hydroelectric power station and two lock chambers." (Danišovič, 1971)

Mr. Lokvenc also reported that the first level the Wolfstahl/Bratislava Waterworks was not possible to construct because of political reasons. (Greguš, 2017)

Mr. Danišovič mentioned alternative designs for the regulation of the Danube between Bratislava and

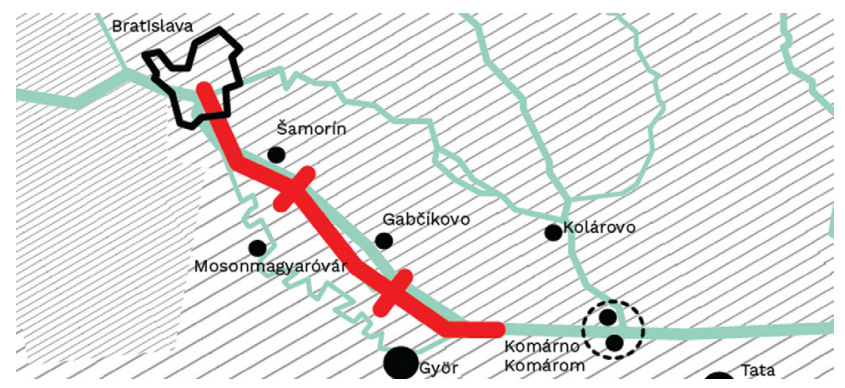

Fig. 10 Scheme of the alternative proposal, drawing: author
Polakovičovo, which included a solution in the natural river bed by creating two lock chambers (Fig. 10). He stated that these proposals were denied because of a significant loss of alluvial forests and economic reasons (doubled investment on power stations, lower productivity).

After the rejection of the 1977 contract by Hungary, Czechoslovakia chose to finish the Waterworks in "Variant C", which was situated completely on the Slovak side. The alternative dam was built in Čunovo instead of the originally planned site near Dunakiliti. (Fig. 9)

\section{The Role of Architects, Urban Planners and Landscape Designers}

The architect Bertold Miček worked for many years in water management and was also active in waterworks Projects. In the $70 \mathrm{~s}$, in the review for Slovak Architects Projekt, he wrote a motivational article for architects and landscape designers to collaborate on water management projects (Míček, 1975). This article coincided with the beginning of the Danube Waterworks project and was influential. The author writes:

"Can we speak about architecture, architectural production in water management or can we just let the architecture be as it happens when assessing the waterworks? I suppose that we not only could, but we have to, it is our duty to solve the aesthetics of these constructions. In recent times, there is always a louder critique - less praise - concerning the architecture of these and the water work at the water management conferences. It concerns mainly the exterior design of the buildings and the environment surrounding our rivers and dams."

He follows with advice on how to design a water work:

"The aesthetic result of water management projects and its surrounding environment is only to be achieved when the architectural proposal follows the work from the complex/general to the specific/detailed. We do not 
construct it as an isolated object, but always as a part of its broader environment, which should then harmonically adapt to the complex organism of the town, village and the whole landscape."

Mr. Miček concludes that water will always influence the architectural works, as it does to all everyday activities. Good collaboration between water management engineers and architects can make our homes, towns, landscapes more beautiful and noble. (Míček, 1975)

Mr. Danišovič was a big fan of architecture in this specific field of construction: He wanted to resolve the best placement and adjustment of the complete water management project into the natural environment, including the architecture of every single object and ensemble of the construction. Both solutions had to ensure the best possible aesthetic effect because the waterworks with its immediate proximity to Bratislava would attract inhabitants of the capital and tourists so that it could be used for recreation and water sports. The architectural and landscape arrangement of the waterworks would require, in comparison to the overall costs a relatively small budget. On the other hand, the effects related to these architectural and landscape designs would be considerable. (Danišovič, 1971)

These words were confirmed by the architects. Il'ja Skoček remembered the role of architects in his words:

"Zlámal was the name of the director of Hydroconsult. So, we agreed with him that we would be responsible for the architecture. We thought that our task was to design just the facades; when we met engineers, they wanted us to work on the whole design from the very beginning and to collaborate with them. So, we did it from scratch with their advice. The technical parameters were developed in this process as well. Especially in the collective of Hydroconsult; we were secondary in this process.

On the presentation of the preliminary project, we had a meeting at Hydroconsult, and the engineers said: "These look like the drawings of our Janka (little girl).". That was architecture for them. So one time I banged my hand on the table and told my colleagues "We are leaving!" and so we did. After 20 minutes, they called us back and apologised.

In the case of a water management project, you cannot change many technical things; the architect has another mission. Our competence was the area of the power station and its buildings. We were not responsible for the design of the environment; we did not analyse or monitor it. It was a pity that we did not deal with it."

Mr. Minárik, a former vice president of the Slovak water management enterprise, also did not remember any of the urban or spatial planners related to the process or preparation of the waterworks. He indicated that all of the decisions were made by the government and its ministries alone.

Mr. Kusý and Mr. Tholt, the architects of the dam, were of the opinion that all of this had to be put aside because the main topics were flood protection, navigation and the production of energy. Kusý explains it using the example of cooperation with other professions.

"The construction is a small wonder as it is. The engineers had to think about so many details we cannot even imagine; they have my respect. However, there was no room to think about urban design or landscape. Those were secondary topics at that time. The main aim was to construct the waterworks. All the project designing was aimed to achieve the maximum effect from an economic point of view I think that even the fact, that they called us to design the few buildings was more than anyone ever expected."

In the final project documentation, anything related to urban or spatial planning was hard to find. We only found the spatial plan for the area of the so-called recreational island containing the settlements of Dobrohošt', Vojka and Bodíky, which was drawn by the state institute for urban and spatial planning (URBION), by the architects Zibrín and Stuchlý. The reason for this is that all the documentation from the state-run institutes were lost or disappeared completely after their restructuring after the revolution in '89 and the separation of Slovakia from the former Czechoslovak federation. This was confirmed by many sources, from Mr. Holčík of the Slovak Water Management Enterprise (SWME), from Mr. Minárik (SWME), and Mr. Kusý and Mr. Skoček, as well as the institutes themselves when asked for the archived documents.

\section{The Process of Architectural Design on the Gabčíkovo Waterworks from the Point of View of the Authors}

We asked the actors and planners about the process of getting the job for projecting the waterworks.

Mr. Skoček recalled:

"Well, it started in a really funny way. There was an association of State Architectural and Project Studios (ŠPTÚ) where my friend and colleague Mr. Boháč was a senior manager. One day, he called me and told me: "Il'ja, you know what? Go to Hydroconsult." So I did. I talked to the director (Mr. Zlámal) and asked him if he could show me what they had already done regarding the proposal for the waterworks so that I could judge the design. He told me: "we haven't designed anything yet. You are going to do it." 
I was surprised in a positive way, that I should design the waterworks on Danube; so, I agreed. I went back to studio and I talked with my friends Mr. Konček and Mr. Titl. But they were a bit hesitant with this idea. Then I asked some other friends Mr. Kusý, Mr. Paňák and Mr. Bauer (junior architects at the office of Konček, Skoček, Titl), if they are able to work on it with me. So we divided the work.

I was cooperating on the design of the power station with a few people from Hydroconsult. There was a Russian structural engineer Mr. Jarosievič and an electrical engineer Mr. Tomášek with whom we started the project. The water power station would have eight turbines, which were divided into eight blocks; the hydroelectric power plant is usually built as a hall. Once in a while, the machines inside have to be checked and in case of breakdown removed by a crane. My colleagues from Hydroconsult had the idea that the crane would not be inside the building because it increases the height of the hall structure. Consequently, the power station has an open roof and the crane is able to cross the hall and take the machines away if necessary.

It was the largest waterworks so all the work was very complicated for the architect, and for whoever had to design and construct it for the first time. I did all the drawings in a scale of 1:200 and some parts in a scale of 1:50; consequently, the drawings were very long. In reality, the power station was longer than $300 \mathrm{~m}$. It has a significant and quite interesting impact on the Danube countryside. I also invited my wife to the process. She designed a very interesting study. A building in the form of a pyramid. However, in the end, the design was sadly dropped, (by the commission lead by Architect Karfík). It was something unusual."

\section{The End of the Architects}

The version of Mr. Skoček

"When I came back from Algeria (1984), the work on the waterworks continued again, but our institute did not want to do it anymore. The director stated: "No, it is a work for Hydroconsult, they should do it." The Institute did not want to take responsibility for the construction, due to the serious and complex nature of the project. Clearly, to build a waterworks it is not a job for an architect. This resulted in our collective being no longer involved in the works."

The version of Mr. Kusý

"The task of the team of Architect Skoček was to design a project for building permit, with all the plans in a scale of 1:100. It took the team almost three years to finish it. However, then they won the competition for the new National Theatre building and stopped working on the
Gabčíkovo project. "I don't want to comment on how it would be if we worked on both of these big projects simultaneously. We were young, like 30-33 years old, I think we could work for 27 hours 8 days a week."

Kusý later describes how the actual appearance of the buildings did not match to their project. (Fig. 11 - original proposal of the watchtower)

"This structure looks completely different; it is a nice example of the situation when an architect does not carry out the project to its realisation. You can see the resemblance between the buildings, but one could be architecture the second is not, just a utilitarian building." (Fig. 12)

\section{Current Approach}

Nowadays, it has become more important to connect significant stakeholders and communities to work together and to plan their environment. It is also because of the experience in this paper, the presented approach towards planning and the shift from the top-down perspective. The planning seems to have become more collaborative. The evidence of this shift is presented through the activities of different NGOs and institutions. In particular, the Central European foundation and its programme "Danube Fund" with its different activities: The Summer Solstice on the River Danube, River Lab Working Group - a group

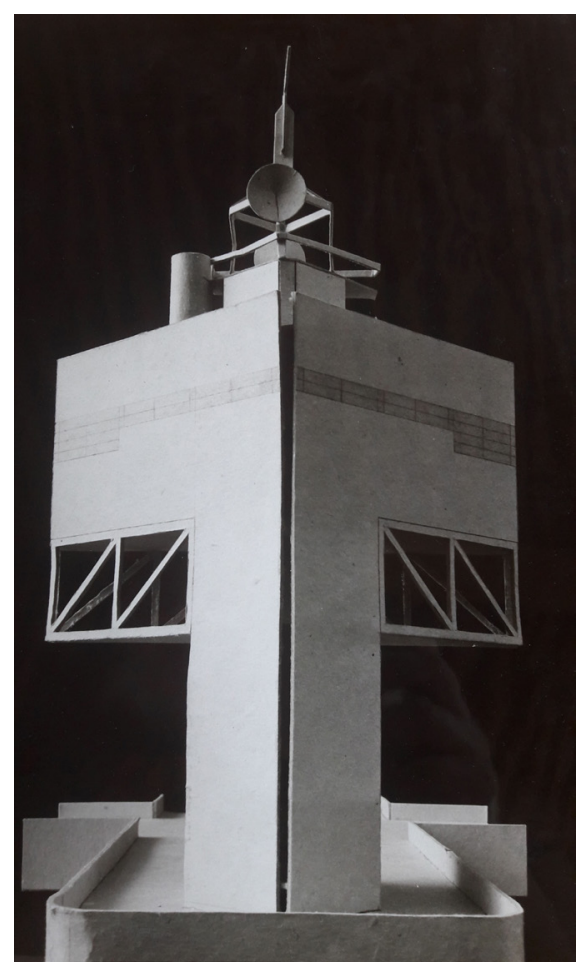

Fig. 11 Physical model of the watchtower by Mr. Paňák, source: Martin Kusý, archive of BKPŠ office 


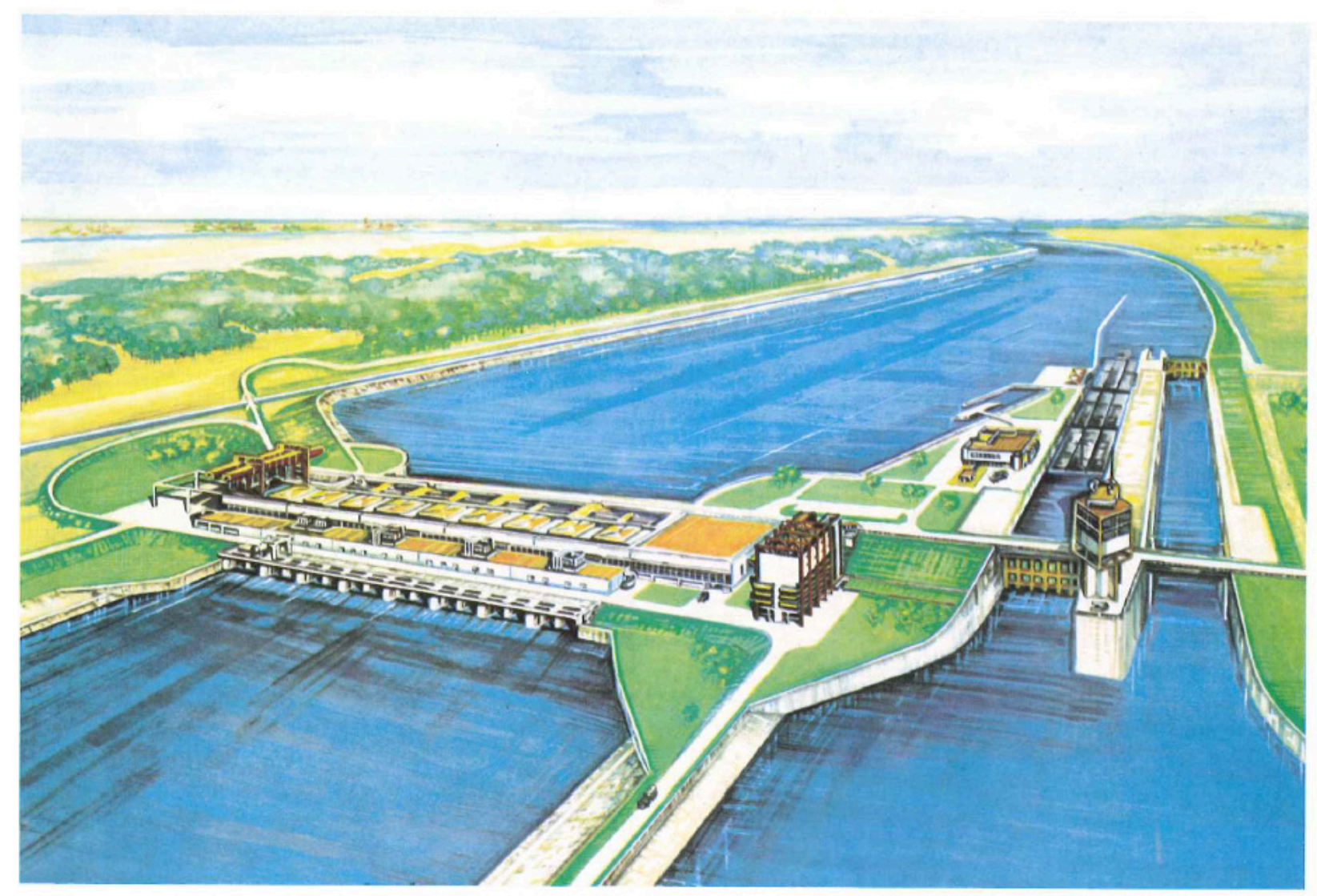

Fig. 12 Isometry of the Waterworks, source: Tholt, Projekt 5-6/1990, pp. 31. (author P. Bauer)

of stakeholders participating on the development of the Danube region in Slovakia. The EGTC Pons Danubiiwhich gathers seven different towns on both the Hungarian and Slovak side, and collaborations funded by the EU in the terms of the Danube strategy - programme DANUrB - gathering seven Danube countries in the scheme of the Interreg Danube Transnational program.

\section{Mental Maps}

Zsófia Nagy carried out research between 2012 and 2013; it is based on socio-anthropological fieldwork carried out in Bős (Gabčíkovo). Nagy's research includes maps drawn by local people (Fig. 13) affected by the construction of the dam. These maps make visible both the process of forgetting and the way memory is imprinted by and into space. The maps show the way construction of the dam and the new Danube canal changed the use of space. Notably, certain spaces and objects in space no longer appear in the maps of individuals born after the dam was built. (Nagy, 2014)

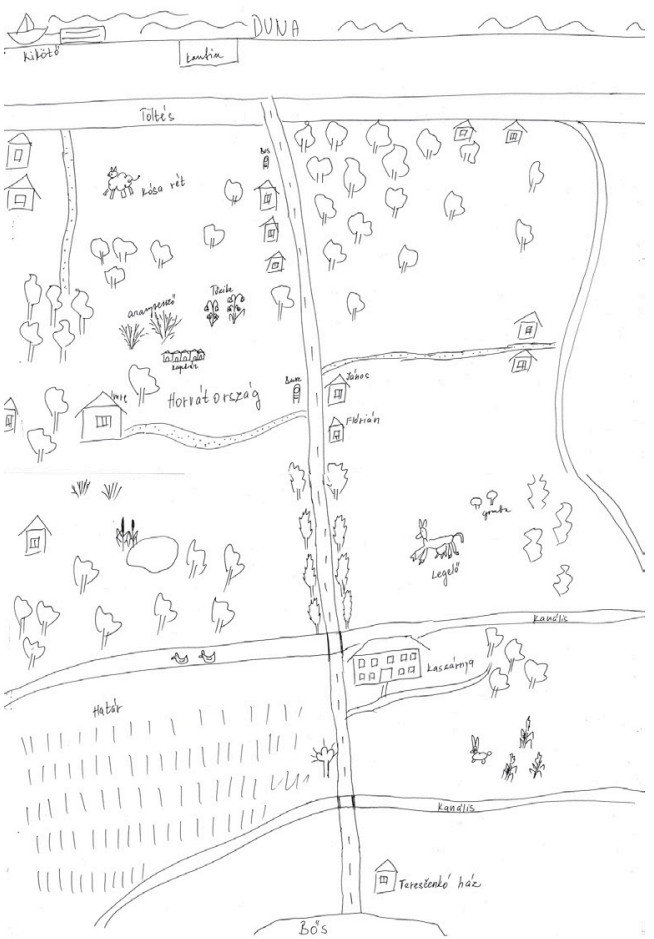

Fig. 13 Mental maps, source: Nagy, Space and Society 2014, pp. 20. (author M. N. born in 1964) 


\section{Conclusion}

The Danube region has its specific landscape that changes with every microregion. The Pannonian basin was unique due to its inland delta, creating a river landscape with many small islands.

The design process and the construction of the Gabčíkovo Waterworks is a spectacular technical monument. It is clear that the technical part of the design was the most important, and the impact on the image of the landscape was not taken into account. There were many problems that could be solved differently but the fact that, even

\section{References}

Čomaj, J. (2012) "Premena vody na elektrinu v našich dejinách", (Changing water to Electricity) [online] Available at: http://snn. sk/premena-vody-na-elektrinu-v-nasich-dejinach/ [Accessed: 8th November 2017] (in Slovak).

Danišovič, P. (1996) "Aj tak(to) sme stavali sústavu vodných diel Gabčíkovo-Nagymaros", (Also in this Way We Constructed the Gabčíkovo-Nagymaros Waterworks) Collection of Memories, AFA, Bratislava, Slovakia. (in Slovak).

Danišovič, P. (1971) "Problémy Dunaja", (Problems of the Danube) Projekt, 150, pp. 398-403. (in Slovak).

Greguš, P. (2002) "Vzt’ah spoločnosti a vodných zdrojov treba riešit' komplexne", (The Relation of Society and Water Resources has to be solved in complex) [online] Available at: http://www.noveslovo. sk/c/20047/Vztah_spolocnosti_a_vodnych_zdrojov_treba_riesit_ komplexne [Accessed: 8th November 2017] (in Slovak). in the time of communism, architects were able to help in the design of such a construction was valuable. However, they solved only individual buildings. The landscape was dealt only from the biological and geological point of view; no one solved the impact on the image of the landscape. The results of this process was a drastic change. History has taught us that this top-down approach to landscape design has to change to create ecologically but also socially sustainable solutions. It is upon our generation of architects, urban and landscape designers to improve the processes to more collaborative and landscape sensitive approaches.

Hruška, E. (1946) "Krajina a její soudobá urbanisace", (Landscape and its contemporary urbanization) B. Pyšvejc, Prague, Czech Republic. (in Czech).

Míček, B. (1975) "Architektúra vo vodnom hospodárstve", (Architecture in water management) Projekt, pp. 30-31. (in Slovak).

Nagy, Zs. (2014) "Constructs of a conflict. Spatial interpretations of the Bős case", Space and Society, 28(1), pp. 62-83. [online] Available at: http://real.mtak.hu/17344/1/2555-6733-1-PB.pdf [Accessed: 13th October 2017]

Tholt, T. (1990) "Vodné diela na Dunaji - áno či nie? Problémy s komplexným využitím Dunaja", (Water works on Danube - yes or no? Problems with complex use of Danube) Projekt, 5-6, pp. 28-31. (in Slovak).

Škvarečková, G. (1977) "Ako využit' Dunaj", (How to use Danube) Projekt, 8 210, pp. 39. (in Slovak). 